\title{
The partisan politics of early childhood education in the German Länder
}

\author{
MARIUS R. BUSEMEYER \\ Department of Political Science and Public Administration, University of Konstanz, Germany \\ E-mail: marius.busemeyer@uni-konstanz.de
}

LINA SEITZL

School of Economics and Political Science, University of St. Gallen, Switzerland

E-mail: lina.seitzl@unisg.ch

\begin{abstract}
This article analyses the role of partisan politics in the recent expansion of early childhood education and care in the German Länder. In contrast to recent work in comparative public policy that often diagnoses a waning of partisan effects, we find broad support for the notion that partisan differences continue to matter in this policy field. The government participation of left-wing parties is positively and significantly associated with changes in public spending on early childhood education, independent of whether this is measured as a percentage of gross domestic product or in terms of per-capita spending. In contrast, left-wing partisanship is not associated with changes in the share of public spending devoted to independent (private) institutions. Coalition status, particularly governing in a Grand Coalition, somewhat mediates these effects. Our empirical analysis is based on the findings from a cross-sectional time-series analysis based on an original data set of spending data for the 16 Länder for the time period between 1992 and 2010.
\end{abstract}

Key words: conservative welfare states, education, partisanship, public childcare

\section{Introduction}

Germany has long been regarded as a laggard when it comes to the public provision of social services such as early childhood education. This has been ascribed to the conservative or Christian democratic nature of Germany's welfare state (Esping-Andersen 1990; Van Kersbergen 1995), which - in line with the principle of subsidiarity - identifies families (and usually mothers) as the primary caregivers for small children. In recent years, however, there have been significant changes in German family and early childhood education and care (ECEC) policies (Fleckenstein et al. 2011; 
Morgan 2012, 2013). Somewhat surprisingly, some of these changes were promoted by Christian democratic leaders in the Federal Government, which supported the expansion of childcare institutions with dedicated subsidies. Scholars have explained this observation by pointing out that the Christian democrats have moved towards the political centre in order to appeal to new electoral constituencies in the aspiring middle classes, particularly women (Naumann 2012; Fleckenstein and Lee 2014).

However, as we argue in this article, this apparent convergence of Christian democrats towards the political centre in childcare policies masks a significant degree of variation at the subnational level of Länder governments. Even though local governments also contribute significantly to the maintenance costs of childcare institutions, Länder governments have been crucial in financing the establishment of the respective infrastructure. In doing this, Länder governments differ enormously in how they make use of available federal funds for childcare expansion and with regard to their willingness to devote additional resources to the expansion of ECEC, leading to significant differences in public spending on ECEC across the Länder. This article explores this variation of policy output across Länder and argues that the partisan composition of governments is associated with differences in the observed output.

Providing an answer to the latter question is the theoretical and empirical aim of this article with implications for partisan theory in general. In recent years, scholars have repeatedly observed that compared with the post-war decades, the explanatory power of partisan factors is waning (Kwon and Pontusson 2010). The most common explanations for this observation are the constraining forces of economic globalisation (Busemeyer 2009a), fiscal austerity or path dependency in welfare state policies (Pierson 2001). Furthermore, expanding public childcare opportunities is a policy, which is very popular with the middle classes (Bonoli 2013). Therefore, parties of different stripes might be equally interested in promoting childcare services in an attempt to capture the median voter.

This article develops a contrasting perspective by showing that in the case of ECEC expansion in Germany, partisanship continues to matter. By exploring the variation in policy output at the subnational rather than the national level, we find that left-wing Länder governments have been willing to invest significantly more resources in the expansion of the public infrastructure of ECEC than their right-wing counterparts, which is a remarkable finding in the face of high problem pressure and the general popularity of childcare provision in Germany. Approaching the issue from the classical perspective of partisan theory (Hibbs 1977), rooted in expectations about economic redistribution, this finding is puzzling, because the expansion of public childcare benefits the middle classes rather than the 
traditional electoral constituencies in the lower-income classes (Van Lancker 2013). Hence, our analysis supports recent work that pays more attention to partisan competition in value-related conflicts about gender roles and family policy as a second dimension of competition in addition to conflicts about economic redistribution (Häusermann 2010; Hieda 2013).

Existing quantitative literature on the partisan politics of childcare provision is scarce and has so far focussed mostly on the international (Lambert 2008; Bonoli and Reber 2010; Hieda 2013) or the local level (Mosimann and Giger 2008; Goerres and Tepe 2012). From an empirical perspective, this article makes a contribution by analysing the determinants of childcare spending at the subnational level of German Länder. For this purpose, we rely on an original data set of public investments in ECEC for children below the age of six years, compiled from official statistics yearbooks for the time period 1992-2010. The study by Andronescu and Carnes (2015) - discussed in greater detail below - comes closest to our approach, but they look at levels of enrolment in childcare for children below the age of three, whereas we study patterns of public spending for public and independent childcare institutions. In addition, their study covers a much shorter time period (2005-2011) compared with ours, which makes it more difficult to trace the effects of changes in government composition over time. All in all, ours is the first study to analyse the association between partisanship and public spending on ECEC at the Länder level.

\section{Partisanship and the politics of early childhood education}

\section{Partisan politics and welfare state research}

There is a long tradition of scholarship that studies the association between partisan composition of governments and policy output (Hibbs 1977; Stephens 1979; Castles 1982; Schmidt 1982). The core expectation of partisan theory is that different parties pursue different policies once in government, and that these differences can be explained by parties' motivations to cater to the interests of particular electoral constituencies. The first generation of scholarship in this tradition derived party preferences from the economic interests of their core electoral supporters, which could be placed on an economic left-right dimension. Over the years, the classical perspective of partisan theory has been expanded, modified and extended. Strøm (1990), for instance, has made the important point that political parties are also keen on gaining elections and winning office, and therefore to a certain extent willing to change their policy positions for strategic reasons. Kitschelt $(1994,1999)$ and others (Kriesi et al. 2006) have shown that party competition has become two-dimensional in the wake of the rise 
of postmaterialism and globalisation. In addition to the economic left-right dimension, parties increasingly compete on a second dimension, which is related to value conflicts between liberal and cosmopolitan values on the one hand and authoritarian, paternalistic values on the other. Social democratic parties have been particularly challenged by these changes, because their traditional electoral constituencies are shrinking, and they need to appeal to new voters in the educated middle classes (Boix 1997; Busemeyer 2009b; Gingrich and Häusermann 2015).

Increasingly, the central tenet of partisan theory - that the balance of power between political parties in government is related to variations in policy output - is being challenged by a set of competing theories in public policy research. One line of thinking goes back to Pierson (1994) as well as Rose and Davies (1994) who argue that institutional and policy legacies have such strong implications for policymaking that partisan actors have little leeway to change policies once in office, contributing to a high degree of path dependency in policymaking. A related, but different argument is put forward in the globalisation literature, which attributes the waning influence of parties on output to the increasingly constraining forces of globalisation (Kittel and Obinger 2003; Kwon and Pontusson 2010). Furthermore, in an age of "permanent austerity" (Pierson 2001), policymakers of different partisan stripes may have little leeway in setting new budgetary priorities because of limited fiscal resources. Finally, more recent scholarship argues that social policy is largely driven by "popular demand" (Brooks and Manza 2006; Rehm 2011), i.e. changes in public opinion. If policymakers are responsive to changing demands, differences between parties in government should diminish in the long run, and the median voter's position should dominate.

All in all, therefore, the role of partisanship as a driver of policy change is contested in the literature, both from a theoretical as well as an empirical perspective. We want to contribute to this debate by studying the effect of partisanship for the case of early childhood education. This is an interesting test case for partisan theory for two reasons: on the one hand, first, expanding the provision of early childhood education is a policy that primarily benefits the working middle classes (Van Lancker 2013). Similar to education (Ansell 2010; Busemeyer 2015), the redistributive implications of investments in ECEC are somewhat unclear. As investing in childcare is a popular policy fuelled by public demands for policies that reconciliate work and family life, both left- and right-wing parties should be in favour of spending increases. On the other hand, second, independent from concerns about economic redistribution, partisan conflicts about childcare provision might rather be motivated by different value orientations or "competing childcare visions" (Andronescu and Carnes 2015, 160). Furthermore, as - in the case of 
Germany - early childhood education is still a policy field, which is institutionally underdeveloped. There should be more leeway for partisan differences to emerge compared with a well-established policy field with a high degree of path dependency.

\section{Scholarship on the politics of early childhood education}

Compared with the large body of literature on the determinants of welfare state policy more generally, research on family policies and ECEC has developed only recently. It is only since the emergence of the social investment debate in the 1990s and 2000s that public childcare came into the focus of comparative welfare state research (Henninger et al. 2008; Lambert 2008; Jensen 2009; Bonoli and Reber 2010; Daly 2010; Leitner 2010; Mätzke and Ostner 2010; Fleckenstein et al. 2011; Morgan 2012, 2013; Fleckenstein and Lee 2014; Oliver and Mätzke 2014; Andronescu and Carnes 2015). Proponents of the social investment "paradigm" argue that the welfare state should invest in active labour market policies and education (Esping-Andersen 2002; Bonoli 2012, 2013; Morel et al. 2012). Public childcare is central to this idea because it increases women's employment opportunities and promotes child development and the accumulation of human capital (Esping-Andersen 2009; StadelmannSteffen 2011; Jenson 2012a, 2012b). Investments in early childhood education can prevent the emergence of inequalities and social problems in later stages of life, contributing to mitigating social inequalities in the long term (Van Lancker 2013).

The ambivalence about the role of partisanship discussed above is also present in existing scholarship on the politics of childcare provision. Roughly speaking, the literature can be divided into three different camps:

Scholars in the first camp argue that other factors besides partisan politics are more important driving forces of policy change in the field of ECEC. For instance, Jensen (2009) posits that institutions, particularly curriculum traditions, are crucial (see also Oliver and Mätzke 2014 for a related argument). Mätzke and Ostner (2010) emphasise the power of ideas: according to their perspective, the recent changes in German family and ECEC policies are a consequence of the fact that "old ideas" about better reconciling work and family life have matured for a significant period of time, so that at some point both parties had to respond to changing family and gender values. Blum (2014) emphasises the transnational diffusion of policy ideas between Germany and Austria. In a quantitative analysis of "maternity-friendly policies", Lambert (2008) finds that union density and institutional veto points have more explanatory power as determinants of policy change than partisanship. 
In contrast to the first camp, work in the second set of contributions recognises the importance of partisanship as a driving force of change, but party competition is regarded less as a source of differentiation between political parties than as a driving force of convergence. In this literature, the cases of Germany as well as other European countries such as the Netherlands and the United Kingdom (UK) are prominently discussed as examples of recent and significant policy changes (Henninger et al. 2008; Daly 2010; Leitner 2010; Morgan 2012, 2013; Fleckenstein and Lee 2014). The case of Germany is often regarded as particularly puzzling, because some of the most important reforms in family and ECEC policies were passed during the Grand Coalition government (consisting of Christian and social democrats), which was in power between 2005 and 2009. Ursula von der Leyen, a prominent member of the Christian democratic CDU, is often regarded as an important political entrepreneur providing leadership as the responsible minister. The apparent turnaround of the CDU from a critic towards a supporter of progressive family and ECEC policies is remarkable and in need of an explanation. For Fleckenstein and Lee (2014, 603), party competition has been the "key political driver in policy expansion" (emphasis in the original) in the field of ECEC and family policies. As is argued by Morgan $(2012,2013)$ as well as Naumann (2012), political parties have strong incentives to appeal to new electoral constituencies, particularly women, who have become more "dealigned" from traditional partisan constituencies compared with men. The public provision of ECEC is a specific policy, which can be used by both left-wing and conservative parties to reforge partisan alliances. Thus, policy change is driven by the convergence of partisan positions rather than their continued divergence, because traditionally conservative parties have promoted the expansion of ECEC in order to reach out to new electoral constituencies in the working middle classes, particularly women.

The third line of thinking in existing scholarship, finally, rather points out the continued differences in party positions. Although most of the contributions in the second camp discussed previously are qualitative case studies of reform processes, the bulk of scholarship in the third camp is made up of quantitative analyses of spending or enrolment data. Comparing policy output in ECEC at the national level in a large set of Organisation of Economic Cooperation and Development (OECD) countries, both Bonoli and Reber (2010) as well as Hieda (2013) show that left-wing government is associated with higher levels of public spending on childcare [which is different from the null findings of Jensen (2009) and Lambert (2008), who, however, use different dependent variables and different time periods of analysis]. The empirical evidence provided by Hieda (2013) suggests that left-wing parties with a left-libertarian profile are most keen on expanding 
ECEC compared with more traditional left-wing parties. In other words, the value orientation of parties matters. What is more, as is argued by Naumann (2012) and Leitner (2010), Christian democratic parties (or other conservatives) may also be torn between a commitment to traditional family values on the one hand - which are still important for their core voters - and strategic appeals to new urban middle-class women and families on the other.

The recent study by Andronescu and Carnes (2015), which explores the variation in ECEC policies across German Länder, confirms the importance of partisanship at the subnational level. Andronescu and Carnes (2015) argue that despite the apparent convergence of policy positions at the federal level in Germany, "competing childcare visions" (Andronescu and Carnes 2015, 160) rooted in different ideological conceptions about the role of women continue to prevail in political parties at the subnational level, partly accounting for the variation in policy output. Complementing analyses of national and subnational variation, there are a few studies that study variation at the local level. This is sensible, because local governments are usually responsible for maintaining and financing childcare facilities to a large extent. Again, existing studies find some evidence for partisan effects. In a study of the level of childcare fees in 95 German cities, Goerres and Tepe (2012) show that fees are substantially higher for middle- and high-income individuals in municipalities, in which left-wing parties hold the majority in city councils. Mosimann and Giger (2008) compare local governments in the Swiss canton of Zurich and reveal a positive association between public ECEC spending and the number of day-care places and the political power of left-wing parties in local councils.

\section{Our argument}

Our argument largely builds on and extends scholarship in the third camp identified in the previous section. Ours is the first study of subnational variation of public spending on ECEC. The study by Andronescu and Carnes (2015) comes closest to ours, but there are a number of important differences. First, they study enrolment rates for children below the age of three, whereas we look at public spending as well as public subsidies to private (independent) institutions. Both analytical perspectives are valid, but they are different. Enrolment rates are determined by policy decisions on the supply of childcare places on the one hand and parental decisions on the use of available facilities on the other. In contrast, public spending is a more direct measure of policy output, so that we would expect stronger effects of partisanship in that case. Second, the period of analysis is much shorter in the study by Andronescu and Carnes (2015) compared with our study (2005-2011 versus 1992-2010). If one is interested in detecting the 
effects of partisanship, having a longer period of observation is important in order to be able to observe changes over time related to changes in government (given that a government is usually in power for four or five years, depending on the Land). Third, Andronescu and Carnes (2015) cannot distinguish between enrolment in public and nonpublic, independent providers. There are, however, important differences between the Länder in the extent to which private nonprofit providers are involved in the provision of ECEC and the extent of public subsidies to these providers. Although our study cannot directly analyse private spending because of a lack of data, we provide a more fine-grained perspective with regard to the determinants of direct public spending and indirect public subsidies to independent institutions, which reveals important differences between government parties. These aspects have not been studied by Andronescu and Carnes (2015). Fourth, we look at public spending on early childhood and preprimary education for children below the age of six, whereas Andronescu and Carnes (2015) look at the share of enrolled children below the age of three. Finally, our study uses a sophisticated set of statistical methods with multiple control variables and robustness checks (see below), whereas Andronescu and Carnes (2015) rely on a simpler estimation design with a limited set of control variables. In sum, our study is the first to systematically analyse the association between partisanship of German Länder governments and spending on early childhood education, complementing existing work on enrolment rates and spending in international comparison.

As stated above, exploring the subnational variation in ECEC spending across German Länder might lead to a reassessment of the German case: the existing literature portrays Germany as a prime example of a significant policy shift from a traditional "male breadwinner" model towards the more progressive social investment type (Leitner 2010; Fleckenstein et al. 2011; Morgan 2013; Fleckenstein and Lee 2014). Although we would not fundamentally disagree with this assessment, the analysis of subnational variation in ECEC policies might show that the supposed turnaround of the Christian Democratic Party has not been as comprehensive as could be assumed on the basis of policy decisions at the federal level.

Länder governments have significant leeway in deciding about the allocation of public spending resources to ECEC. Legally speaking, the provision of ECEC lies within the responsibility of the municipalities according to the principle of local self-government enshrined in Article 28(2) of the German Basic Law. Nevertheless, the Länder governments play a decisive role in determining the amount of state funding for ECEC, because they are responsible for large-scale investments in the infrastructure, whereas local governments are mostly in charge of maintenance (supported with additional funding from the federal level since 2008). Since the 1990s, the 
public provision of childcare has been massively expanded. In 1992, policymakers established a legal entitlement for receiving public day care for every child between three and six years of age. This regulation was expanded by the Childcare Funding Act of 2008 (Kinderförderungsgesetz) to children under three years of age. Most of the decisions related to the expansion of childcare opportunities have been made at the federal or the Land level with limited involvement at the local level (Münder 2009). According to the legal "principle of related action" (Konnexitätsprinzip), the costs for this expansion must therefore not be attributed to the local governments as they had no formal say in these decisions. As a consequence, the Länder governments are legally obliged to transfer financial resources to the municipalities in order to finance the expansion of public childcare. The amount of financial allocation that is transferred to the local governments is determined in separate laws for each Land (Goerres and Tepe 2012, 171), which opens up many different possibilities of how exactly the transfer of resources from the subnational to the local level should be organised. Furthermore, the influence of the Federal Government is more limited as it might seem at first sight. It can only indirectly influence policymaking at the Land level by making available subsidies for the expansion of childcare, but these funds can be used in different ways by the subnational government (MBJS 2013). Hence, there remains a significant leeway for Länder governments to promote different policies for the expansion of childcare institutions.

Our core hypothesis then is that these differences in policy output are systematically associated with differences in the partisan composition of subnational (Länder) governments. The government participation of left-wing parties is expected to be positively associated with increasing public provision of childcare, whereas the opposite should hold for the case of Christian democrats. Partisan differences are primarily rooted in different normative conceptions about the role of women in the labour market and in the family rather than in different redistributive implications of investment in ECEC. Compared with the national level, where conservative political leaders have moved to the middle ground for strategic reasons, partisan differences are likely to continue to matter more at the subnational Länder level, because political elites at this level are closer to party members at the base, who are likely to hold more radical views than political leaders at the top (Iversen 1994).

At the Länder level in Germany, the left wing of the party spectrum is divided between two major parties: the social democratic SPD, which is more powerful in the Western Länder, and the more traditionally socialist Left Party (Die Linke), which continues to receive high levels of electoral support in the East. The Left Party usually positions itself to the left of the 
SPD on social issues. Even though there are continuous conflicts between the SPD and the Left Party, the latter - when in government in the Eastern Länder - has become a regular left-wing social democratic/socialist party. In addition to the SPD and the Left Party, the Greens is the third party on the left of the German party spectrum. The Greens comes closest to the type of left-liberal party that Hieda (2013) has identified as the main driving force of expansion in ECEC, since it typically represent middle-class voters with a liberal value orientation. In sum, when it comes to the issue of ECEC, all three of Germany's left-wing parties should have a similar positive orientation towards the expansion of ECEC, particularly by expanding public provision.

In contrast to these left-wing parties, the Christian democrats should be much more reluctant to expand early childhood education. In comparison with secular, conservative or liberal parties, Christian democrats are expected to be even more opposed to the public provision of childcare because of their ideology rooted in Catholic doctrine. In Christian democratic ideology, the principle of subsidiarity is key (Van Kersbergen 1995, 188). According to this principle, the state should refrain from intervening if other social entities, primarily the family, are better placed to provide social services such as childcare. In line with this argument, Esping-Andersen (1999) introduced the notion of "familialism" into welfare state research, which refers to the role of the family as provider of social services in contrast to the market and the state.

As part of the institutional legacy of a corporatist, conservative welfare state, private, independent and often Church-affiliated institutions are also an important part of the childcare infrastructure in Germany. Therefore, in addition to public spending on childcare, we also analyse the share of public subsidies devoted to private childcare institutions relative to all spending on childcare in a given Land. For this indicator, we expect fewer, if any, partisan differences. This is because the enthusiasm of left-wing parties to subsidise childcare is expected to be more muted when investment is channelled to private institutions. Vice versa, Christian democratic parties might be more willing to support the expansion of childcare, when public investment favours independent Church-affiliated institutions.

Finally, we also expect that partisanship will be affected by the composition of government coalitions. To a certain extent, our measure of partisanship automatically takes into account this coalitional effect (see discussion below), because pure left-wing (or right-wing) governments are scored higher than "mixed" government coalitions. In spite of that, the debate about the expansion of childcare might be different in a Grand Coalition setting. Although Grand Coalitions have been a rare event at the federal level, they have been more common at the subnational level (for instance in Baden-Wurttemberg, Mecklenburg-Western Pomerania, Thuringia and Berlin in the 1990s as well as in Brandenburg, Saxony, 
Saxony-Anhalt, Schleswig-Holstein and Hamburg in the 2000s). We hypothesise that the positive effect of left partisanship on public ECEC spending will be muted in a Grand Coalition setting, because left parties cannot promote their favoured policy because of the opposition of the coalition partner. Instead, Grand Coalition governments might promote the build-up of childcare infrastructure by subsidising the private sector instead, because this solution represents a compromise between social and Christian democratic policy goals.

In sum, we test the following hypotheses:

H1: Left-wing governmental power is associated with increases in public spending on ECEC.

$\mathrm{H} 2$ : There are no significant partisan differences with regard to the share of public subsidies to private (independent) childcare institutions.

H3: The effect of left-wing partisanship is muted in Grand Coalition governments, whereas spending on private independent institutions is expected to increase.

Besides partisanship, there are a number of other potential determinants of childcare spending, which are discussed in the literature, e.g. female employment participation, demographic pressures or population density. As we focus on the role of partisanship, we include these factors as control variables and discuss their potential impact in the empirical section below.

\section{Data and methods}

For the empirical analysis, we use data on public spending for early childhood education provided by the Federal Statistical Office. This public spending data combines spending from the Länder governments itself as well as local governments, aggregated at the Länder level. We focus on three dependent variables: public spending on public day-care facilities relative to the Länder gross domestic product (GDP) (1) and relative to population size (i.e. per-capita spending) (2). In addition, we look at the share of public spending on early childhood education that goes to independent, i.e. private, institutions (3). Ideally, we would have liked to include private spending on ECEC as well, both as a dependent and as an independent variable. Controlling for (past) levels of private spending would take into account the fact that the private (independent) sector might be more developed in some Länder than in others, which could slow down the expansion of public services in these cases. Unfortunately, we only have data for public spending, also because private spending (i.e. mostly fees) 
varies significantly across local governments (see Goerres and Tepe 2012). In the robustness section of this article, however, we include (lagged) levels of public spending on private institutions, which is a proxy variable related to the size (and importance) of the independent sector in different Länder. Unfortunately, the Federal Statistical Office does not distinguish between public spending on childcare facilities and public spending on youth welfare in Berlin and Hamburg before 2002. We therefore had to exclude these cases in the multivariate regression analysis below.

Before we discuss the control variables and the statistical methods, we present some descriptive statistics of the main dependent variables (see also Tables A.1 and A.2 for more descriptive statistics and details on data sources). In Figure 1, we display the share of public spending on ECEC as percentage of GDP between 1992 and 2010. On average, we see an overall increase in public spending on day-care facilities from an average of $0.72 \%$ of GDP in 1992 to $1.07 \%$ of GDP in 2010 . However, as expected, there are significant differences between the Länder. In the Western Länder, the share of public spending increased steadily. In contrast, spending for ECEC accounted for a larger share of GDP in 1992 than in 2002 in Eastern Germany (with the exception of Saxony). In Saxony-Anhalt and Mecklenburg-Western Pomerania, the spending level of the early 1990s has not been achieved anymore in the latter periods. The high spending levels in the Eastern German Länder shortly after reunification are surely related to the institutional and political legacy of the German Democratic Republic (GDR). As Figure 1 shows, this pattern can still be observed today. In 2010, the three Western German Länder lagged behind

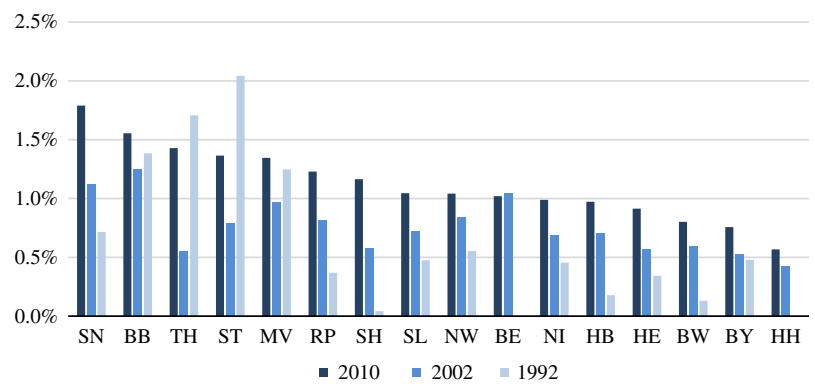

Figure 1 Public spending on early childhood education and care as \% of GDP.

Note: Own illustration based on data provided by the Federal Statistical Office (2012); for 1992, there are no data available for Berlin and Hamburg. SN = Saxony; $\mathrm{BB}=$ Brandenburg; $\mathrm{TH}=$ Thuringia; $\mathrm{ST}=$ Saxony-Anhalt $\mathrm{MV}=$ Mecklenburg-Western Pommerania; $\mathrm{RP}=$ Rhineland-Palatinate; $\mathrm{SH}=$ Schleswig-Holstein; $\mathrm{SL}=$ Saarland; $\mathrm{NW}=$ North Rhine-Westphalia; $\mathrm{BE}=$ Berlin; $\mathrm{NI}=$ Lower Saxony; $\mathrm{HB}=$ Bremen; $\mathrm{HE}=$ Hesse; $\mathrm{BW}=$ Baden-Wuerttemberg; $\mathrm{BY}=$ Bavaria; $\mathrm{HH}=$ Hamburg. 


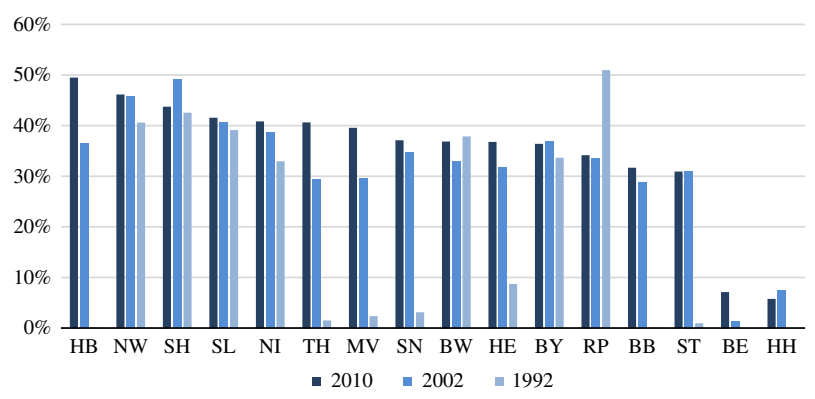

Figure 2 Share of public spending on early childhood education and care going to private institutions.

Note: Own illustration based on data provided by the Federal Statistical Office (2012); for 1992, there are no data available for Berlin and Hamburg.

the Eastern states. For instance, spending on ECEC as a percentage of GDP was twice as high in Saxony compared with the three Western Länder with the lowest spending levels (Hamburg, Bavaria and Baden-Wurttemberg). The highest spending Western Länder governments in 2010 were RhinelandPalatinate and Schleswig-Holstein.

As part of the institutional legacy of a corporatist, conservative welfare state, private, independent and often Church-affiliated institutions play an important role in Germany's ECEC system (Kreyenfeld 2010). Besides overall levels of spending, another dimension of variation across Länder is therefore the role of private (independent) day-care institutions in ECEC, which are to a large extent also dependent on public subsidies and private childcare fees (Statistisches Bundesamt 2010,29). Figure 2 shows that there has been a large overall increase in the share of public spending going to private childcare institutions between 1992 and 2002. Since then, private ECEC facilities account for around one-third of overall public spending. The sharp increase within a short period can be explained by the developments in the Eastern Länder. Because of their socialist legacy, private childcare facilities played almost no role in Eastern Germany in the early 1990s. Within 10 years, they managed to catch up with the rest of the Länder. Private institutions are especially important in Bremen, taking up almost $50 \%$ of overall public spending in 2010, but also in North-Rhine Westphalia, Schleswig-Holstein and the Saarland. Interestingly, in the other two city-states of Berlin and Hamburg, private ECEC institutions play only a marginal role.

Summing up, there is ample evidence of a high degree of variation in policy output in ECEC, both across time as well as across Länder. Although there is an overall increasing trend in public spending, there is a lot of variation with regard to the strength of this trend. Disaggregating the broad 
categories of Eastern and Western Länder also reveals a significant variation within these groups of cases, indicating that there could be other factors explaining the variation in output besides economic well-being or institutional legacies related to differences between East and West Germany. Our prime suspect is, of course, partisan politics.

Our most important independent variables measure the partisan composition of governments at the Länder level and were taken from the data set of Schmidt (2011) on the cabinet shares of government parties in the Länder. More specifically, we use a broader measure of left-wing partisanship, which combines the cabinet share of social democrats (SPD), the Greens and the Left party (Die Linke). This summary measure is preferable to a simple measure of government participation of social democrats only for several reasons. First, the broader measure takes into account the role of party coalitions. It could be expected that coalition governments between the SPD and the Left (e.g. in Mecklenburg-Western Pomerania between 1998 and 2006 and in Berlin between 2001 and 2011) or between the SPD and the Greens would pursue the expansion of early childhood education more vigorously compared with a Grand Coalition between the CDU and the SPD (e.g. in Baden-Wurttemberg between 1992 and 1996). By operationalising partisanship as cabinet share, our measure differentiates between left-wing government coalitions on the one hand (with values towards the upper end of the scale between 0 and 100) and mixed coalitions (these are almost always Grand Coalitions between the CDU and the SPD) on the other (with values around 50). Second, not taking into account the Left Party as a left-wing government party would in effect exclude many observations from the Eastern German Länder. In these cases, the Left Party is stronger than the SPD in electoral terms and pursues a reformist centre-left policy strategy once in government.

As mentioned above, our specific measure of partisanship already takes into account the composition of government coalitions to a certain extent. Nevertheless, we also include a dummy variable, which indicates whether the respective Land has been governed by a Grand Coalition or not in the robustness section of this article and explore the interaction effects of this variable with leftwing partisanship. Furthermore, it is important to point out that our measure of partisanship as cabinet shares is not only the measure, which is most often used in analyses of the role of political parties in policymaking, but is also particularly adequate in the German context. Decisions about major investment programmes such as the expansion of early childhood education are not taken by individual ministers or the state premier himself/herself alone, but need to be passed as laws both by the cabinet as well as the state parliaments. Hence, a measure capturing the balance of power between different political parties in government is a more precise and appropriate measure of partisanship than looking at the political party of individual ministers or the state premier only. 
We include a number of control variables. First, we include the share of the population below the age of 30 to capture demographic demand. One plausible expectation is that a larger population share of young people should increase spending on childcare (see Busemeyer 2007 for a similar finding with regard to total education spending), particularly in the long run. In the short term, however, a strong increase in the demand for childcare might lead to resource scarcity, when the expansion of the supply of childcare cannot keep up with the increased demand. This might result in lower levels of per-capita spending.

Second, the level of female labour market participation is included as another indicator of socioeconomic demand. Again, we expect a positive association in the long run. The causal arrow between female labour market participation and the availability of childcare probably runs in both directions as the expansion of childcare institutions also opens up new employment perspectives in the public sector.

Third, we take into account population density, which is significantly higher in the city-states (Bremen, Hamburg and Berlin) compared with the remaining Länder. Our expectations with regard to the impact of this variable are ambivalent: on the one hand, higher levels of population density could increase the demand for childcare, driving up spending. On the other hand, the competition for scarce public resources could be more intense in densely populated areas, which could lead to lower levels of per-capita spending as the same amount of resources needs to be spread across more individuals (similar to the effect of an increase in demand as mentioned above).

Fourth, we include the GDP per capita as an indicator of economic wellbeing. We expect a positive association between this variable on public spending on childcare, particularly for per-capita spending. This is because there is a higher probability that wealthier Länder can afford to invest in the expansion of new public services such as childcare, whereas poorer Länder will be more concerned with maintaining the status quo.

Finally, we also include a dummy variable that captures differences between Eastern and Western Länder related to different institutional and political legacies as mentioned above. We also include a dummy for citystates (Bremen, Hamburg and Berlin). It might be the case that spending on childcare is higher in city-states because there is a stronger demand for childcare in large cities and city/state governments might be more vulnerable to lobbying from influential middle-class parents. However, to a large extent, these effects should already be captured by the other control variables. In some model specifications, we use Länder fixed effects, which control for unobserved heterogeneity between states.

Our data set comprises data for the 16 Länder governments for the time period 1992-2010. In terms of methods, analysing this kind of data poses 
considerable problems and no easy solutions are available (Kittel and Winner 2005; Plümper et al. 2005; Beck 2007). The basic unit of analysis is a countryyear. All variables have been standardised before the analysis (i.e. set to a mean of 0 and a standard deviation of 1 ). In this type of data, there is often serial correlation between the errors of time series within individual countries (i.e. spending at time $t$ will be affected by spending at $t-1$ ). Furthermore, the variance is expected to differ between units (panel heteroscedasticity), and errors tend to be correlated across countries for given years (Beck and Katz 1995, 636). In order to deal with the latter two problems, Beck and Katz $(1995,1996)$ recommend the usage of panel-corrected standard errors, which we also do in this article. Beck and Katz $(1995,1996)$ also advise to include the lagged dependent variable (LDV) as an independent variable to deal with the problem of serial correlation. This approach has been strongly criticised, because it overly depresses the explanatory power of the remaining independent variables (Achen 2000). In addition, data such as ours might suffer from the problem of nonstationary time series.

In order to deal with these problems, we use two different model specifications. Our preferred model specification is the increasingly popular error-correction model (ECM) (Beck 1991; De Boef and Keele 2008) (see Busemeyer 2009b, Iversen and Cusack 2000 for applications). This specification is advisable when the dependent variable is nonstationary. Nonstationarity, i.e. a nonrandom trend in a time series, is a problem because it leads to wrong coefficient estimates (Kittel and Winner 2005). The upward trend in spending on early childhood-education documented above indicates that this might be a problem in our case. As recommended by Maddala and Wu (1999), we applied a Fisher test and an Im-PesaranShin test that confirmed that at least some of the time series are nonstationary. Therefore, the usage of an ECM is advisable. In the ECM, the dependent variable is defined in changes (first differences) of spending rather than levels as in other model specifications. In contrast to time series of levels of spending, time series of changes are usually stationary. On the left-hand side of the regression equation, the ECM includes the lagged level of the dependent variable (spending), whose coefficient estimate should have a negative sign, because this indicates a reversal of short-term trends in the dependent variable to some kind of long-term average. The model specification also includes lagged levels and lagged changes (lagged by one year) of the independent variables. The coefficient estimates on the lagged changes capture short-term effects of the respective variable, whereas the coefficient of the lagged level relates to long-term effects. In the main part of the analysis (Table 1), we include the above-mentioned dummies for city-states and East-West differences. In the robustness section (see Table A.3), we run the models with and without Länder fixed effects. In general, the inclusion of 
Table 1. Determinants of changes in spending on early childhood education and care (ECEC), error-correction model

\begin{tabular}{|c|c|c|c|}
\hline Dependent Variables & $\begin{array}{l}(1) \\
\text { Public Spending on ECEC as } \\
\% \text { of GDP (First Difference) }\end{array}$ & $\begin{array}{l}\text { (2) } \\
\text { Public Spending on ECEC, } \\
\text { Per Capita (First Difference) }\end{array}$ & $\begin{array}{l}\text { Share of Public Spending on ECEC Going } \\
\text { to Private Institutions (First Difference) }\end{array}$ \\
\hline ECEC spending as \% of GDP (lagged level) & $-0.143(0.0253) * * *$ & & \\
\hline ECEC spending per capita (lagged level) & & $-0.0679(0.0419)$ & \\
\hline ECEC spending for private institutions (lagged level) & & & $-0.176(0.0352) * * *$ \\
\hline Left-wing partisanship (first difference) & $-0.0550(0.0394)$ & $-0.0141(0.0466)$ & $0.0189(0.0471)$ \\
\hline Left-wing partisanship (lagged level) & $0.0542(0.0158) * * *$ & $0.0414(0.0199) * *$ & $0.00552(0.0208)$ \\
\hline Population under 30 (first difference) & $1.151(0.681) *$ & $1.305(0.903)$ & $0.247(0.388)$ \\
\hline Population under 30 (lagged level) & $-0.0797(0.0457)^{*}$ & $-0.0484(0.0551)$ & $-0.0617(0.0373)^{*}$ \\
\hline Female labour market participation (first difference) & $-0.356(0.154) * *$ & $-0.363(0.191) *$ & $-0.0615(0.110)$ \\
\hline Female labour market participation (lagged level) & $0.00384(0.0439)$ & $0.0212(0.0564)$ & $-0.0424(0.0266)$ \\
\hline Population density (first difference) & $5.174(4.723)$ & $5.565(7.791)$ & $9.014(7.064)$ \\
\hline Population density (lagged level) & $-0.125(0.0725)^{*}$ & $-0.157(0.102)$ & $-0.216(0.0688) * * *$ \\
\hline GDP per capita (first difference) & $-0.291(0.381)$ & $0.457(0.507)$ & $-0.271(0.228)$ \\
\hline GDP per capita (lagged level) & $0.0115(0.0330)$ & $0.0475(0.0441)$ & $-0.0133(0.0403)$ \\
\hline East-west dummy & $0.162(0.151)$ & $0.0864(0.186)$ & $-0.00982(0.0955)$ \\
\hline City-state (dummy) & $-0.0133(0.129)$ & $0.110(0.210)$ & $0.190(0.150)$ \\
\hline Constant & $0.216(0.0870) * *$ & $0.297(0.118)^{* *}$ & $0.0688(0.0447)$ \\
\hline Observations & 269 & 269 & 269 \\
\hline$R^{2}$ & 0.272 & 0.141 & 0.151 \\
\hline Number of Länder & 16 & 16 & 16 \\
\hline
\end{tabular}

Note: Standard errors in parentheses.

GDP = gross domestic product.

$* * \mathrm{p}<0.01, * \mathrm{p}<0.05, * \mathrm{p}<0.1$. 
fixed effects in this model should not make a big difference, because the dependent variable is defined in changes.

The second model specification we use is the "Beck-Katz standard" (Plümper et al. 2005), in which the dependent and independent variables are given in levels (see Table 2). We also include Länder fixed effects, and we use one-year lags of all independent variables as (somewhat imperfect) solution to potential endogeneity problems. Because of the inclusion of fixed effects (Länder dummies) and the LDV on the right-hand side of the equation, this model specification essentially turns into a dynamic model even though it is specified in levels, because the only variation that the remaining independent variables besides the LDV can account for is the yearly change in the dependent variable. From a theoretical perspective, this is plausible as we are interested in explaining the association between left partisanship and changes in spending.

\section{Empirical analysis}

Tables 1 and 2 present the main findings of our empirical analysis. In both tables, we calculate one model for each of the three dependent variables mentioned above (spending on ECEC as a percentage of GDP, spending per capita and the share of spending that goes to private institutions). Table 1 presents ECMs, in which the dependent variables are defined as changes and which include East-West and city-state dummies. Table A.3 runs the same models with and without Länder fixed effects. In Table 2, we display findings from models using the Beck-Katz standard specification.

Our core finding is that left partisanship is indeed positively associated with changes in public spending on early childhood education, independent of whether this is measured as a percentage of GDP or in terms of per-capita spending. To repeat, in the ECM specification, the coefficient estimates of the independent variables that measure changes can be interpreted as shortterm effects that dissipate over time at a rate defined by the parameter of the LDV. The coefficients of the lagged-level independent variables, in contrast, indicate long-term associations between these and the dependent variable. Thus, Models 1 and 2 in Table 1 show that the effect of left partisanship on spending is mostly a long-term effect, as the coefficient on the change variable is not statistically significant. To provide a concrete estimate of the magnitude of the long-term effect, simulating a change in government from one without any left party involvement to one consisting entirely of leftwing parties, the predicted change in spending as percentage of GDP is 0.0031 , which is roughly the size of $1 \mathrm{SD}$ in the sample with an overall mean of 0.0077 (see Table A.1 for descriptive statistics). With regard to percapita spending, a similar simulation yields an effect of 107.47 , which is 
Table 2. Determinants of levels in spending on early childhood education and care (ECEC), Beck-Katz model specification

\begin{tabular}{|c|c|c|c|}
\hline Dependent Variables & $\begin{array}{c}(1) \\
\text { Public Spending on ECEC as } \\
\% \text { of GDP (Level) }\end{array}$ & $\begin{array}{l}(2) \\
\text { Public Spending on ECEC, } \\
\text { Per Capita (Level) }\end{array}$ & $\begin{array}{l}\text { (3) } \\
\text { Share of Public Spending on ECEC Going } \\
\text { to Private Institutions (Level) }\end{array}$ \\
\hline ECEC spending as $\%$ of GDP (lagged level) & $0.784(0.0362) * * *$ & & \\
\hline ECEC spending per capita (lagged level) & & $0.838(0.0509) * * *$ & \\
\hline ECEC spending for private institutions (lagged level) & & & $0.585(0.0549) * * *$ \\
\hline Left-wing partisanship (lagged level) & $0.0581(0.0211) * * *$ & $0.0396(0.0221)^{*}$ & $0.0175(0.0185)$ \\
\hline Population under 30 (lagged level) & $-0.0749(0.0495)$ & $0.00318(0.0584)$ & $0.0142(0.0336)$ \\
\hline Female labour market participation (lagged level) & $0.109(0.0670)$ & $0.209(0.0828)^{* * *}$ & $-0.169(0.0497)^{* * *}$ \\
\hline Population density (lagged level) & $-5.505(1.656)^{* * *}$ & $-5.522(2.571)^{* *}$ & $-4.614(2.007)^{* *}$ \\
\hline GDP per capita (lagged level) & $0.105(0.113)$ & $0.263(0.156)^{*}$ & $0.678(0.109)^{* * *}$ \\
\hline Constant & $-2.008(0.602)^{* * *}$ & $-1.984(0.962)^{* * *}$ & $-1.954(0.749)^{* * *}$ \\
\hline Fixed effects & Yes & Yes & Yes \\
\hline Observations & 269 & 269 & 269 \\
\hline$R^{2}$ & 0.905 & 0.901 & 0.920 \\
\hline Number of Länder & 16 & 16 & 16 \\
\hline
\end{tabular}

Note: Standard errors in parentheses.

GDP $=$ gross domestic product.

$* * \mathrm{p}<0.01, * * \mathrm{p}<0.05, * \mathrm{p}<0.1$. 
roughly 1.5 times 1 SD with a mean of 177 euros. Thus, the magnitude of the effects is quite sizable.

The positive and statistically significant association between left partisanship and public spending on ECEC is confirmed in Table 2, where we use the Beck-Katz standard model specification. Again, we find a positive and statistically significant association between left partisanship and ECEC spending, independent of whether we look at spending as percentage of GDP (Model 1) or per capita (Model 2). However, the significance level drops to the $10 \%$ level in the latter case.

Probing the robustness of our findings further confirms the hunch that the association between partisanship and spending as percentage of GDP is stronger than the association between partisanship and per-capita spending. In Table A.3, the ECMs without Länder fixed effects (Models 1 and 3) confirm the positive and statistically significant association, but the effect turns insignificant in the case of per-capita spending, once fixed effects are included (Model 4 versus Model 2). Somewhat surprisingly, Model 2 in Table A.3 reveals a significant negative short-term effect of left partisanship on public spending on ECEC, although it is significant only at the $10 \%$ level. This is difficult to interpret in a straightforward manner, but could indicate a certain "upper limit" effect: left partisanship has a positive longterm effect on spending, but short-term changes in partisanship can go along with relatively less spending in the near term. Table A.4 adds a further control to the regressions of public ECEC spending: lagged levels in the share of public subsidies to the private (independent) institutions. This variable barely reaches $(10 \%$ level $)$ significance in regressions of public ECEC spending and is not significant for per-capita spending. Hence, the relative size of the independent sectors does not seem to influence the dynamics of public spending in a strong manner. Most importantly, as the models show, the effect of partisanship (particularly on spending as percentage of GDP) remains positive and significant.

As expected, we do not find any statistical association between left partisanship and the share of public spending on ECEC that goes to independent institutions (Models 3 in Tables 1 and 2 as well as Models 5 and 6 in Table A.3). As many independent institutions are affiliated with Christian churches, Christian democrats in government might be less opposed to supporting these with public moneys, which in total cancels out the effect of partisanship on this dependent variable.

We explore this possibility further in Table 3, where we add an interaction term between left partisanship and the coalition status [the Grand Coalition dummy takes the value of 1 in cases where the left (i.e. in this case the SPD) governs jointly with the CDU]. First of all, it is important to note that the main effects of partisanship observed in Tables 1 and 2 do not 
Table 3. Interaction between left partisanship and Grand Coalition dummy variable

\begin{tabular}{|c|c|c|c|c|}
\hline \multirow[b]{2}{*}{ Dependent Variables } & \multicolumn{2}{|c|}{ Public Spending on ECEC as \% of GDP (Level) } & \multicolumn{2}{|c|}{$\begin{array}{c}\text { Share of Public Spending on ECEC Going to Private } \\
\text { Institutions (Level) }\end{array}$} \\
\hline & $(1)$ & $(2)$ & (3) & (4) \\
\hline ECEC spending as \% of GDP (lagged level) & $0.783(0.0364) * * *$ & $0.765(0.0355) * * *$ & & \\
\hline ECEC spending for private institutions (lagged level) & & & $0.587(0.0550) * * *$ & $0.583(0.0541) * * *$ \\
\hline Left-wing partisanship (lagged level) & $0.0580(0.0210) * * *$ & $-0.0174(0.0287)$ & $0.0179(0.0189)$ & $0.0555(0.0289) *$ \\
\hline Grand Coalition (dummy) & $0.0064(0.0256)$ & $-0.0192(0.0237)$ & $-0.0314(0.0248)$ & $-0.0182(0.0246)$ \\
\hline Grand Coalition $\times$ left-wing partisanship & & $-0.140(0.0380) * * *$ & & $0.0699(0.0340) * *$ \\
\hline Population under 30 (lagged level) & $-0.0736(0.0505)$ & $-0.106(0.0493) * *$ & $0.00842(0.0338)$ & $0.0251(0.0371)$ \\
\hline Female labour market participation (lagged level) & $0.107(0.0660)$ & $0.124(0.0624) * *$ & $-0.158(0.0477) * * *$ & $-0.162(0.0483) * * *$ \\
\hline Population density (lagged level) & $-5.368(1.686) * * *$ & $-5.451(1.671) * *$ & $-5.274(1.882) * * *$ & $-5.370(1.881) * * *$ \\
\hline GDP per capita (lagged level) & $0.107(0.114)$ & $0.0531(0.109)$ & $0.664(0.109) * * *$ & $0.695(0.111) * * *$ \\
\hline Constant & $-1.965(0.603) * * *$ & $-1.992(0.605) * * *$ & $-2.180(0.711) * * *$ & $-2.224(0.710) * * *$ \\
\hline Fixed effects & Yes & Yes & Yes & Yes \\
\hline Observations & 269 & 269 & 269 & 269 \\
\hline$R^{2}$ & 0.905 & 0.909 & 0.921 & 0.922 \\
\hline Number of Länder & 16 & 16 & 16 & 16 \\
\hline
\end{tabular}

Note: Standard errors in parentheses.

ECEC $=$ early childhood education and care; GDP $=$ gross domestic product.

$* * \mathrm{p}<0.01, * * \mathrm{p}<0.05, * \mathrm{p}<0.1$ 
change when the Grand Coalition dummy is included (Model 1 and 3). Models 2 and 4 reveal some interesting findings: first of all, the effect of left partisanship on public ECEC spending as percentage of GDP turns from positive to negative. Vice versa, we now find a positive association between left partisanship in Grand Coalitions and public spending on private institutions. This could indicate that left-wing parties in Grand Coalitions are forced to make a compromise with the Christian democratic coalition partners in the sense that the goal of expanding childcare services has to be promoted by public subsidies to independent institutions rather than by investing in public institutions only. However, a caveat in this analysis has to be added: the interaction between coalition status and left partisanship singles out the SPD as one of three left-wing parties. Hence, the differences between the models of Table 3 and the previous models could also be explained by the fact that other left-wing parties, in particular Die Linke, are more prone to promote public provision of childcare services only.

We briefly comment on the performance of the control variables. In the ECM in Table 1, the explanatory power of socioeconomic control variables is relatively low (see also Table A.3). The population share of individuals below the age of 30 is one of the few exceptions. However, contrary to what could be expected, the association is negative, i.e. public spending on ECEC is lower both as percentage of GDP as well as in terms of per-capita spending in relatively young Länder (although the latter is not statistically significant). Calculating per-capita spending relative to the population below the age of 30 and not, as we have done, relative to the total population, does not change the results in any significant way (not shown here for reasons of space). The negative association is a bit harder to explain in the case of spending as percentage of GDP. The effect is primarily driven by between-case variation, as the inclusion of fixed effects (see Table A.3, model 2) turns it insignificant. As in many OECD countries, there is a general trend towards population ageing in Germany. In our sample, the share of below-30s drops from $39 \%$ in 1992 to $31 \%$ in 2010 . As, at the same time, public spending on early childhood education increased significantly for reasons that were not directly related to changing demographics, but changing family relations and labour market institutions, we find a negative association between the share of below-30s and public spending on ECEC. The models also show a positive short-term effect (which is even significant in the case of Model 1), indicating that short-term increases in the demographic demand for childcare are indeed associated with increasing spending.

Furthermore, population density is negatively associated with spending as percentage of GDP, per-capita spending and the share of spending that goes to independent institutions, particularly in the Beck-Katz model 
specifications (Table 2). The large magnitude of this effect is explained by the fact that there are huge differences in population density between the city-states and the remaining Länder. Hence, to a large extent, this variable works as a city-state dummy variable in the models in Table 2 (even though we include Länder fixed effects here). The negative association of population density with spending might again be related to resource-competition effects. Higher levels of population density could trigger a more intense competition for limited public resources, in childcare and beyond. However, Model 6 in Table A.3 using fixed effects shows a positive and significant short-term effect of population density on changes in the share devoted to independent institutions. This might be explained by the fact that strong increases in demand are first met with increasing spending on independent institutions, before fully public ones are established.

Somewhat surprisingly, female labour force participation does not emerge as a strong predictor of changes in public spending, even though a positive effect could have been expected in this case. A simple bivariate correlation between the two variables indeed documents such a positive association (0.57), but as our model specifications shift the focus to withincase variation, this effect cannot be confirmed. We even find cases of a negative and significant association for the short-term effects in ECMs (see Models 1 and 2 in Table 1 and Models 1 through 3 in Table A.3). In the Beck-Katz model specification (Model 2, Table 2), we find a positive association with per-capita spending, but a negative one with the share of public spending devoted to independent institutions (Model 3). All in all, these mixed results should not be overinterpreted - most likely they simply document the nonrobustness of the association between female labour force participation and spending on ECEC. Finally, differences in economic well-being measured in terms of GDP per capita do not matter much, although we find a significant positive effect on per-capita spending (Model 2 in Table 2) and on the public spending share devoted to private institutions (Model 3).

\section{Conclusions}

This article has studied the role of partisan politics in the recent expansion of ECEC in the German Länder. We found broad support for the notion that partisan differences continue to matter in this policy field. The government participation of left-wing parties (SPD, Die Linke or the Greens) is positively and significantly associated with changes in public spending on early childhood education, independent of whether this is measured as a percentage of GDP or in terms of per-capita spending, although the association is stronger in the case of the former compared with 
the latter. In contrast and as expected, left-wing partisanship is not statistically associated with changes in the share of public spending devoted to independent (private) institutions. However, coalition status matters as well. In Grand Coalitions, left partisanship is associated with lower levels of public spending on ECEC, but with a higher share of public spending devoted to independent institutions. Compared with the explanatory power of partisan variables, socioeconomic factors matter less.

Therefore, our article can be taken as evidence that partisan theory continues to have explanatory power, even in an age of austerity and economic globalisation. However, we would hasten to add, this is a consequence of the fact that ECEC had been an underdeveloped and not yet fully institutionalised policy field until recently. It might well be the case that in the future partisan effects on spending might become less important in this case as well, as spending laggards are catching up with the pioneers. The "modernisation" agenda of party leaders of the CDU at the national level may eventually contribute to a realignment of party positions at lower levels. Furthermore, the law stipulating a legal entitlement for parents to a place in childcare for children below the age of three triggered a significant further expansion of ECEC in many Länder. In the long term, partisan differences (and legacies of partisan struggles over the expansion of ECEC) might show up less in terms of contemporary spending levels, but rather in differences in the institutional design of childcare systems as is already apparent with regard to the role of independent (private) institutions.

Our article also holds more general implications for partisan theory. The first is to pay more attention to the fact that political parties as organisations can be internally heterogeneous. This is particularly the case in federalist countries, where subnational party organisations also have the chance to occupy government offices and implement policies. In our case, the strategically motivated movement of the CDU party leadership towards a progressive policy position is delimited by subnational parties' continued commitment to more conservative positions. The second (and partly related) implication is to pay more attention to the role of partisan politics in later stages of the implementation phase of large-scale policy programmes. The Grand Coalition at the national level passed highly visible and widely popular family and ECEC policies, but the necessity to pass additional legislation at the subnational level to actually implement these large-scale investment plans opened up a whole new partisan game. As debates about the details of public financing and investment are not necessarily widely reported in the media, this allowed party politicians to adopt a more traditional, less office-seeking and more policy-seeking stance on these issues. 


\section{Acknowledgement}

We thank the anonymous reviewers and the editor of this journal for very helpful suggestions and comments. We are not aware of any potential conflicts of interest.

\section{References}

Achen C. H. (2000) Why Lagged Dependent Variables Can Suppress the Explanatory Power of Other Independent Variables. Paper presented at the Annual Meeting of the Political Methodology Section of the American Political Science Association, July 20-22, University of Michigan, Ann Arbor, MI.

Andronescu C. G. and Carnes M. E. (2015) Value Coalitions and Policy Change: The Impact of Gendered Patterns of Work, Religion and Partisanship on Childcare Policy Across German States. Journal of European Social Policy 25(2): 159-174.

Ansell B. W. (2010) From the Ballot to the Blackboard: The Redistributive Political Economy of Education. Cambridge: Cambridge University Press.

Beck N. (1991) Comparing Dynamic Specifications: The Case of Presidential Approval. Political Analysis 3(1): 51-87.

Beck N. (2007) From Statistical Nuisances to Serious Modelling: Changing How we Think About the Analysis of Time-Series-Cross-Section Data. Political Analysis 15(2): 97-100.

Beck N. and Katz J. N. (1995) What To Do (and Not to Do) With Time-Series CrossSection Data. American Political Science Review 89(3): 634-647.

Beck N. and Katz J. N. (1996) Nuisance Vs. Substance: Specifying and Estimating Time-SeriesCross-Section Models. Political Analysis 6(1): 1-36.

Blum S. (2014) No Need to Reinvent the Wheel: Family Policy Transfers in Germany and Austria. Policy Studies 35(4): 357-376.

Boix C. (1997) Political Parties and the Supply Side of the Economy: The Provision of Physical and Human Capital in Advanced Economies, 1960-1990. American Journal of Political Science 41(3): 814-845.

Bonoli G. (2012) Active Labour Market Policy and Social Investment: A Changing Relationship. In Morel N., Palier B. and Palme J. (eds.), Towards a Social Investment Welfare State? Ideas, Policies and Challenges. Bristol and Chicago, IL: Policy Press, 181-204.

Bonoli G. (2013) The Origins of Active Social Policy: Labour Market and Childcare Policies in a Comparative Perspective. Oxford and New York: Oxford University Press.

Bonoli G. and Reber F. (2010) The Political Economy of Childcare in OECD Countries: Explaining Cross-National Variation in Spending and Coverage Rates. European Journal of Political Research 49(1): 97-118.

Brooks C. and Manza J. (2006) Social Policy Responsiveness in Developed Democracies. American Sociological Review 71(3): 474-494.

Busemeyer M. R. (2007) The Determinants of Public Education Spending in 21 OECD Democracies, 1980-2001. Journal of European Public Policy 14(4): 582-610.

Busemeyer M. R. (2009a) From Myth to Reality: Globalization and Public Spending in OECD Countries Revisited. European Journal of Political Research 48(4): 455-482.

Busemeyer M. R. (2009b) Social Democrats and the New Partisan Politics of Public Investment in Education. Journal of European Public Policy 16(1): 107-126.

Busemeyer M. R. (2015) Skills and Inequality: The Political Economy of Education and Training Reforms in Western Welfare States. Cambridge and New York: Cambridge University Press. 
Castles F. G. (1982) The Impact of Parties on Public Expenditure. In Castles F. G. (ed.), The Impact of Parties: Politics and Policies in Democratic Capitalist States. London: Sage, 21-96.

Daly M. (2010) Shifts in Family Policy in the UK Under New Labour. Journal of European Social Policy 20(5): 433-443.

De Boef S. and Keele L. (2008) Taking Time Seriously. American Journal of Political Science 52(1): 184-200.

Esping-Andersen G. (1990) The Three Worlds of Welfare Capitalism. Cambridge: Polity Press.

Esping-Andersen G. (1999) Social Foundations of Postindustrial Economies. Oxford and New York: Oxford University Press.

Esping-Andersen G. (2002) A Child-Centred Social Investment Strategy. In Esping-Andersen G. (ed.), Why We Need a New Welfare State. Oxford and New York: Oxford University Press, 26-67.

Esping-Andersen G. (2009) The Incomplete Revolution: Adapting to Women's New Roles. Cambridge: Polity Press.

Fleckenstein T. and Lee S. C. (2014) The Politics of Postindustrial Social Policy: Family Policy Reforms in Britain, Germany, South Korea, and Sweden. Comparative Political Studies 47(4): 601-630.

Fleckenstein T., Saunders A. M. and Seeleib-Kaiser M. (2011) The Dual Transformation of Social Protection and Human Capital: Comparing Britain and Germany. Comparative Political Studies 44(12): 1622-1650.

Gingrich J. and Häusermann S. (2015) The Decline of the Working-Class Vote, the Reconfiguration of the Welfare Support Coalition and Consequences for the Welfare State. Journal of European Social Policy 25(1): 50-75.

Goerres A. and Tepe M. (2012) Für die Kleinen ist uns nichts zu teuer? Kindergartengebühren und ihre Determinanten in Deutschlands 95 bevölkerungsreichsten Städten zwischen 2007 und 2010. der moderne staat 6(1): 169-190.

Häusermann S. (2010) The Politics of Welfare State Reform in Continental Europe: Modernization in Hard Times. Cambridge and New York: Cambridge University Press.

Henninger A., Wimbauer C. and Dombrowski R. (2008) Demography as a Push Toward Gender Equality? Current Reforms of German Family Policy. Social Politics: International Studies in Gender, State \& Society 15(3): 287-314.

Hibbs D. A. J. (1977) Political Parties and Macroeconomic Policy. American Political Science Review 71(4): 1467-1487.

Hieda T. (2013) Politics of Childcare Policy Beyond the Left-Right Scale: Postindustrialization, Transformation of Party Systems and Welfare State Restructuring. European Journal of Political Research 52(4): 483-511.

Iversen T. (1994) The Logics of Electoral Politics: Spatial, Directional, and Mobilizational Effects. Comparative Political Studies 27(2): 155-189.

Iversen T. and Cusack T. R. (2000) The Causes of Welfare State Expansion: Deindustrialization or Globalization? World Politics 52(3): 313-349.

Jensen C. (2009) Institutions and the Politics of Childcare Services. Journal of European Social Policy 19(1): 7-18.

Jenson J. (2012a) A New Politics for the Social Investment Perspective: Objectives, Instruments, and Areas of Intervention in Welfare Regimes. In Bonoli G. and Natali D. (eds.), The Politics of the New Welfare State. Oxford: Oxford University Press, 21-44.

Jenson J. (2012b) Redesigning Citizenship Regimes After Neoliberalism: Moving Towards Social Investment. In Morel N., Palier B. and Palme J. (eds.), Towards a Social Investment Welfare State? Ideas, Policies and Challenges. Bristol: The Policy Press, 61-87.

Kitschelt H. (1994) The Transformation of European Social Democracy. Cambridge and New York: Cambridge University Press. 
Kitschelt H. (1999) European Social Democracy Between Political Economy and Electoral Competition. In Kitschelt H., Lange P., Marks G. and Stephens J. D. (eds.), Continuity and Change in Contemporary Capitalism. Cambridge, New York and Melbourne: Cambridge University Press, 317-345.

Kittel B. and Obinger H. (2003) Political Parties, Institutions, and the Dynamics of Social Expenditure in Times of Austerity. Journal of European Public Policy 10(1): 20-45.

Kittel B. and Winner H. (2005) How Reliable is Pooled Analysis in Political Economy? The Globalization-Welfare State Nexus Revisited. European Journal of Political Research 44(2): 269-293.

Kreyenfeld M. (2010) Soziale Ungleichheit und Kinderbetreunng: Eine Analyse der sozialen und ökonomischen Determinanten der Nutzung von Kindertageseinrichtungen. Wiesbaden: VS Verlag.

Kriesi H., Grande E., Lachat R., Dolezal M., Bornschier S. and Frey T. (2006) Globalization and the Transformation of the National Political Space: Six European Countries Compared. European Journal of Political Research 45(6): 921-956.

Kwon H. Y. and Pontusson J. (2010) Globalization, Labour Power and Partisan Politics Revisited. Socio-Economic Review 8(2): 251-281.

Lambert P. A. (2008) The Comparative Political Economy of Parental Leave and Child Care: Evidence From Twenty OECD Countries. Social Politics: International Studies in Gender, State \& Society 15(3): 315-344.

Leitner S. (2010) Germany Outpaces Austria in Childcare Policy: The Historical Contingencies of "Conservative" Childcare Policy. Journal of European Social Policy 20(5): 456-467.

Maddala G. S. and Wu S. (1999) A Comparative Study of Unit Roots Tests With Panel Data and a New Simple Test. Oxford Bulletin of Economics and Statistics 61(4): 631-652.

Mätzke M. and Ostner I. (2010) The Role of Old Ideas in the New German Family Policy Agenda. German Policy Studies/Politikfeldanalyse 6(3): 119-162.

MBJS (2013) Länderübersicht Kita: Finanzierungsregelungen. Potsdam: Ministerium für Bildung, Jugend und Sport Brandenburg.

Morel N., Palier B. and Palme J. (2012) Social Investment: A Paradigm in Search of a New Economic Model and Political Mobilization. In Morel N., Palier B. and Palme J. (eds.), Towards a Social Investment Welfare State? Ideas, Policies and Challenges. Bristol and Chicago, IL: Policy Press, 353-376.

Morgan K. J. (2012) Promoting Social Investment Through Work-Family Policies: Which Nations Do it and Why. In Morel N., Palier B. and Palme J. (eds.), Towards a Social Investment Welfare State? Ideas, Policies and Challenges. Bristol and Chicago, IL: Policy Press, 153-177.

Morgan K. J. (2013) Path Shifting of the Welfare State: Electoral Competition and the Expansion of Work-Family Policies in Western Europe. World Politics 65(1): 73-115.

Mosimann A. and Giger N. (2008) Zwischen Parteipolitik und gesellschaftlicher Notwendigkeit: Familienergänzende Kinderbetreuung auf kommunaler Ebene. Soziale Welt 59(3): 227-246.

Münder J. (2009) Das Kinderförderungsgesetz: Änderungen, Fragen, Probleme. Neue Praxis 1/2009: 3-16.

Naumann I. (2012) Childcare Politics in the "New" Welfare State: Class, Religion, and Gender in the Shaping of Political Agendas. In Bonoli G. and Natali D. (eds.), The Politics of the New Welfare State. Oxford: Oxford University Press, 158-181.

Oliver R. J. and Mätzke M. (2014) Childcare Expansion in Conservative Welfare States: Policy Legacies and the Politics of Decentralized Implementation in Germany and Italy. Social Politics: International Studies in Gender, State \& Society 21(2): 167-193.

Pierson P. (1994) Dismantling the Welfare State? Reagan, Thatcher, and the Politics of Retrenchment. Cambridge: Cambridge University Press. 
Pierson P. (2001) The New Politics of the Welfare State. Oxford, New York: Oxford University Press.

Plümper T., Tröger V. E. and Manow P. (2005) Panel Data Analysis in Comparative Politics: Linking Method to Theory. European Journal of Political Research 44(2): 327-354.

Rehm P. (2011) Social Policy by Popular Demand. World Politics 63(2): 271-299.

Rose R. and Davies P. L. (1994) Inheritance in Public Policy: Change Without Choice in Britain. Yale, CT: Yale University Press.

Schmidt M. G. (1982) Woblfahrtsstaatliche Politik unter bürgerlichen und sozialdemokratischen Regierungen: Ein internationaler Vergleich. Frankfurt a.M. and New York: Campus.

Schmidt M. G. (2011) Kabinettsitzanteile der Parteien in den deutschen Bundesländern. Heidelberg: Institut für politische Wissenschaft.

Stadelmann-Steffen I. (2011) Dimensions of Family Policy and Female Labour Market Participation: Analysing Group-Specific Policy Effects. Governance: An International Journal of Policy, Administration, and Institutions 42(2): 331-357.

Statistisches Bundesamt (2010) Finanzen der Kindertageseinrichtungen in freier Trägerschaft. Wiesbaden: Statistisches Bundesamt.

Stephens J. D. (1979) The Transition From Capitalism to Socialism. London: Macmillan.

Strøm K. (1990) A Behavioural Theory of Competitive Political Parties. American Journal of Political Science 34(2): 565-598.

Van Kersbergen K. (1995) Social Capitalism: A Study of Christian Democracy and the Welfare State. London and New York: Routledge.

Van Lancker W. (2013) Putting the Child-Centred Investment Strategy to the Test: Evidence for the EU27. European Journal of Social Security 15(1): 4-27. 


\section{Appendix}

Table A.1. Descriptive statistics

\begin{tabular}{lccccc}
\hline \hline Variables & $n$ & Mean & SD & Minimum & Maximum \\
\hline ECEC spending (\% GDP) & 285 & 0.00771 & 0.00344 & 0.000425 & 0.02043 \\
ECEC spending (per capita) & 285 & 177.47 & 71.33 & 8.53 & 409.81 \\
ECEC spending for private & 285 & 0.296 & 0.139 & 0.000086 & 0.576 \\
Left-wing partisanship & 304 & 48.48 & 41.86 & 0 & 100 \\
Population share under 30 & 304 & 0.34 & 0.29 & 0.275 & 0.428 \\
Population density & 304 & 665.92 & 1014.76 & 70.82 & 3915.05 \\
Female labour market & 304 & 65.99 & 6.42 & 64.8 & 78 \\
$\quad$ participation & & & & & \\
GDP per capita & 304 & 24744.1 & 7753.4 & 9105.95 & 49434.4 \\
\hline \hline
\end{tabular}

Note $:$ ECEC = early childhood education and care; GDP = gross domestic product.

\section{Table A.2. Data sources}

\begin{tabular}{ll}
\hline \hline $\begin{array}{l}\text { Public spending on early childhood } \\
\text { education and care }\end{array}$ & Statistical Yearbooks of the Federal Statistical Office \\
$\begin{array}{l}\text { Cabinet share of left parties } \\
\text { Share of the population below the } \\
\text { age of } 30\end{array}$ & Statistical Yearbooks of the Federal Statistical Office \\
Female labour market participation & Representative household sample of the Federal \\
rate & Statistical Office (Mikrozensus) \\
Population density & Statistical Yearbooks of the Federal Statistical Office \\
GDP & National Accounts Statistics of the Federal Statistical \\
& Office \\
\hline \hline
\end{tabular}

Note: GDP $=$ gross domestic product. 
Table A.3. Error-correction model with and without FE

\begin{tabular}{|c|c|c|c|c|c|c|}
\hline \multirow[b]{2}{*}{ Dependent Variables } & \multicolumn{2}{|c|}{$\begin{array}{l}\text { Public Spending on ECEC as } \\
\% \text { of GDP (First Difference) }\end{array}$} & \multicolumn{2}{|c|}{$\begin{array}{l}\text { Public Spending on ECEC, } \\
\text { Per Capita (First Difference) }\end{array}$} & \multicolumn{2}{|c|}{$\begin{array}{l}\text { Share of Public Spending on } \\
\text { ECEC Going to Private } \\
\text { Institutions (First Difference) }\end{array}$} \\
\hline & (1) & $(2)$ & (3) & (4) & $(5)$ & (6) \\
\hline ECEC spending as \% of GDP (lagged level) & $\begin{array}{l}-0.139 \\
(0.0240) * *\end{array}$ & $\begin{array}{l}-0.196 \\
(0.0358) * * *\end{array}$ & & & & \\
\hline $\begin{array}{l}\text { ECEC spending per capita } \\
\quad \text { (lagged level) }\end{array}$ & & & $\begin{array}{l}-0.0719 \\
(0.0384)^{*}\end{array}$ & $\begin{array}{l}-0.163 \\
(0.0561) * *\end{array}$ & & \\
\hline $\begin{array}{l}\text { ECEC spending for private institutions } \\
\quad \text { (lagged level) }\end{array}$ & & & & & $\begin{array}{l}-0.183 \\
(0.0346) * * *\end{array}$ & $\begin{array}{l}-0.438 \\
(0.0546) * * *\end{array}$ \\
\hline $\begin{array}{l}\text { Left-wing partisanship } \\
\text { (first difference) }\end{array}$ & $\begin{array}{l}-0.0539 \\
(0.0382)\end{array}$ & $\begin{array}{l}-0.0723 \\
(0.0410)^{*}\end{array}$ & $\begin{array}{l}-0.00904 \\
(0.0451)\end{array}$ & $\begin{array}{r}-0.0407 \\
(0.0446)\end{array}$ & $\begin{array}{c}0.0243 \\
(0.0470)\end{array}$ & $\begin{array}{l}-0.0161 \\
(0.0376)\end{array}$ \\
\hline $\begin{array}{l}\text { Left-wing partisanship } \\
\text { (lagged level) }\end{array}$ & $\begin{array}{l}0.0497 \\
(0.0144) * * *\end{array}$ & $\begin{array}{l}0.0399 \\
(0.0218)^{*}\end{array}$ & $\begin{array}{l}0.0437 \\
(0.0166) * * *\end{array}$ & $\begin{array}{c}0.0376 \\
(0.0255)\end{array}$ & $\begin{array}{c}0.0128 \\
(0.0228)\end{array}$ & $\begin{array}{c}0.00251 \\
(0.0185)\end{array}$ \\
\hline $\begin{array}{l}\text { Population under } 30 \\
\text { (first difference) }\end{array}$ & $\begin{array}{l}0.848 \\
(0.497)^{*}\end{array}$ & $\begin{array}{c}0.688 \\
(0.774)\end{array}$ & $\begin{array}{l}1.083 \\
(0.677)\end{array}$ & $\begin{array}{c}0.787 \\
(0.979)\end{array}$ & $\begin{array}{c}0.184 \\
(0.291)\end{array}$ & $\begin{array}{l}-0.131 \\
(0.426)\end{array}$ \\
\hline $\begin{array}{l}\text { Population under } 30 \\
\quad \text { (lagged level) }\end{array}$ & $\begin{array}{l}-0.102 \\
(0.0360) * * *\end{array}$ & $\begin{array}{r}-0.0573 \\
(0.0553)\end{array}$ & $\begin{array}{r}-0.0616 \\
(0.0434)\end{array}$ & $\begin{array}{c}0.0248 \\
(0.0694)\end{array}$ & $\begin{array}{l}-0.0621 \\
(0.0318) *\end{array}$ & $\begin{array}{l}-0.0257 \\
(0.0409)\end{array}$ \\
\hline $\begin{array}{l}\text { Female labour market participation } \\
\quad \text { (first difference) }\end{array}$ & $\begin{array}{l}-0.344 \\
(0.150) *\end{array}$ & $\begin{array}{l}-0.327 \\
(0.159) * *\end{array}$ & $\begin{array}{l}-0.356 \\
(0.187) *\end{array}$ & $\begin{array}{l}-0.280 \\
(0.189)\end{array}$ & $\begin{array}{c}-0.0690 \\
(0.111)\end{array}$ & $\begin{array}{l}-0.111 \\
(0.106)\end{array}$ \\
\hline $\begin{array}{l}\text { Female labour market participation } \\
\text { (lagged level) }\end{array}$ & $\begin{array}{c}0.0401 \\
(0.0212)^{*}\end{array}$ & $\begin{array}{c}0.0463 \\
(0.0699)\end{array}$ & $\begin{array}{c}0.0464 \\
(0.0285)\end{array}$ & $\begin{array}{c}0.113 \\
(0.0830)\end{array}$ & $\begin{array}{l}-0.0413 \\
(0.0225)^{*}\end{array}$ & $\begin{array}{l}-0.183 \\
(0.0581) * * *\end{array}$ \\
\hline $\begin{array}{l}\text { Population density } \\
\text { (first difference) }\end{array}$ & $\begin{array}{c}6.109 \\
(4.704)\end{array}$ & $\begin{array}{c}9.396 \\
(6.570)\end{array}$ & $\begin{array}{l}3.752 \\
(7.634)\end{array}$ & $\begin{array}{l}12.90 \\
(9.543)\end{array}$ & $\begin{array}{l}5.243 \\
(7.437)\end{array}$ & $\begin{array}{l}26.84 \\
(7.540) * * *\end{array}$ \\
\hline $\begin{array}{l}\text { Population density } \\
\text { (lagged level) }\end{array}$ & $\begin{array}{l}-0.0902 \\
(0.0237) * * *\end{array}$ & $\begin{array}{l}-4.957 \\
(1.550) * * *\end{array}$ & $\begin{array}{l}-0.0926 \\
(0.0325) * * *\end{array}$ & $\begin{array}{l}-5.132 \\
(2.536) * *\end{array}$ & $\begin{array}{l}-0.151 \\
(0.0422) * *\end{array}$ & $\begin{array}{l}-5.288 \\
(2.145)^{* *}\end{array}$ \\
\hline
\end{tabular}


Table A.3: Continued

\begin{tabular}{|c|c|c|c|c|c|c|}
\hline \multirow[b]{2}{*}{ Dependent Variables } & \multicolumn{2}{|c|}{$\begin{array}{l}\text { Public Spending on ECEC as } \\
\% \text { of GDP (First Difference) }\end{array}$} & \multicolumn{2}{|c|}{$\begin{array}{l}\text { Public Spending on ECEC, } \\
\text { Per Capita (First Difference) }\end{array}$} & \multicolumn{2}{|c|}{$\begin{array}{l}\text { Share of Public Spending on } \\
\text { ECEC Going to Private } \\
\text { Institutions (First Difference) }\end{array}$} \\
\hline & (1) & (2) & (3) & (4) & (5) & (6) \\
\hline $\begin{array}{l}\text { GDP per capita } \\
\text { (first difference) }\end{array}$ & $\begin{array}{c}-0.326 \\
(0.355)\end{array}$ & $\begin{array}{l}-0.155 \\
(0.377)\end{array}$ & $\begin{array}{c}0.478 \\
(0.480)\end{array}$ & $\begin{array}{c}0.592 \\
(0.506)\end{array}$ & $\begin{array}{l}-0.221 \\
(0.231)\end{array}$ & $\begin{array}{c}-0.0280 \\
(0.212)\end{array}$ \\
\hline $\begin{array}{l}\text { GDP per capita } \\
\text { (lagged level) }\end{array}$ & $\begin{array}{l}-0.0340 \\
(0.0335)\end{array}$ & $\begin{array}{c}0.111 \\
(0.121)\end{array}$ & $\begin{array}{c}0.0389 \\
(0.0364)\end{array}$ & $\begin{array}{l}0.350 \\
(0.170)^{* *}\end{array}$ & $\begin{array}{c}0.0152 \\
(0.0265)\end{array}$ & $\begin{array}{l}0.656 \\
(0.123)^{* * *}\end{array}$ \\
\hline Constant & $\begin{array}{l}0.232 \\
(0.0860) * * *\end{array}$ & $\begin{array}{l}-1.701 \\
(0.581) * * *\end{array}$ & $\begin{array}{l}0.318 \\
(0.117)^{* * * *}\end{array}$ & $\begin{array}{l}-1.825 \\
(0.965)^{*}\end{array}$ & $\begin{array}{l}0.0915 \\
(0.0453)^{* * *}\end{array}$ & $\begin{array}{l}-2.203 \\
(0.804)^{* * *}\end{array}$ \\
\hline Fixed effects & No & Yes & No & Yes & No & Yes \\
\hline Observations & 269 & 269 & 269 & 269 & 269 & 269 \\
\hline$R^{2}$ & 0.268 & 0.332 & 0.138 & 0.207 & 0.147 & 0.333 \\
\hline Number of Länder & 16 & 16 & 16 & 16 & 16 & 16 \\
\hline
\end{tabular}

Note: Standard errors in parentheses.

ECEC $=$ early childhood education and care; GDP $=$ gross domestic product.

$* * \mathrm{p}<0.01, * \mathrm{p}<0.05, * \mathrm{p}<0.1$. 
Table A.4. Controlling for lagged levels of public subsidies to private institutions

\begin{tabular}{lcc}
\hline \hline & $(1)$ & $(2)$ \\
Dependent Variables & Public Spending on ECEC as \% of GDP (Level) & Public Spending on ECEC, Per Capita (Level) \\
\hline ECEC spending as \% of GDP (lagged level) & $0.779(0.0364)^{* * * *}$ & $0.824(0.0521)^{* * *}$ \\
ECEC spending per capita (lagged level) & & $0.0362(0.0219)^{* *}$ \\
Left-wing partisanship (lagged level) & $0.0544(0.0211)^{* * *}$ & $0.0118(0.0616)$ \\
Population under 30 (lagged level) & $-0.0683(0.0523)$ & $0.268(0.0970)^{* * *}$ \\
Female labour market participation (lagged level) & $0.154(0.0767)^{* * *}$ & $-4.364(2.488)^{*}$ \\
Population density (lagged level) & $-4.447(1.588)^{* * *}$ & $0.111(0.184)$ \\
GDP per capita (lagged level) & $-0.0358(0.148)$ & $0.104(0.0663)$ \\
ECEC spending for private institutions (lagged level) & $0.0871(0.0462)^{* *}$ & $-1.518(0.931)$ \\
Constant & $-1.577(0.584)^{* * *}$ & Yes \\
Fixed effects & Yes & 269 \\
Observations & 269 & 0.903 \\
$R^{2}$ & 0.907 & 16 \\
Number of Länder & 16 & 16 \\
\hline \hline
\end{tabular}

Note: Standard errors in parentheses.

ECEC $=$ early childhood education and care; GDP $=$ gross domestic product.

$* * \mathrm{p}<0.01, * \mathrm{p}<0.05, * \mathrm{p}<0.1$ 